УДК 327.7/.8:929 Хартвиг Н. С.

DOI https://doi.org/10.31212/zradova.17.rusijaisrbija.ziv.247-261

Др Милана ЖИВАНОВИТ

Институт за новију историју Србије

milana.zivanovic@yahoo.com

Др Милана ЖИВАНОВИЧ

Институт новейшей истории Сербии

\title{
Смрт и погреб руског посланика у Београду Николаја Хенриковича Хартвига 1914. г.
}

Смерть и погребение российского посла Николая Генриковича Гартвига в 1914 г.

Период између Сарајевског атентата 28. јуна 1914. г. и почетка аустро-угарских ратних дејстава против Србије месец дана касније, познат под називом „јулска криза“, обележен је низом догађаја*. Важност овог историјског контекста за државе Европе, ${ }^{1}$ разумљива је са становишта праћења развоја дешавања, која су резултирала сукобом светских размера. Међутим, у случају Србије, овај период је носио још једну димензију, директно повезану са приликама изазваним атентатом на Франца Фердинанда. То је била смрт посланика Русије на српском двору, Николаја Хенриковича Хартвига. Последице овог чина - реаговање целокупног друштва и елите у Београду не треба сматрати изолованим од атмосфере која је владала у Србији након атентата у Сарајеву. Реакције њеног јавног мњења на политичке потезе Двојне монархије, ${ }^{2}$ имале су знатан утицај на

\footnotetext{
* Чланак је резултат рада на пројекту Традиција и трансформација - историјско наслеђе и национални идентитети у Србији у 20. веку (№ 47019), при Институту за новију историју Србије, који финансира Министарство просвете, науке и технолошког развоја Републике Србије.

10 јулској кризи и Првом светском рату: Mitrović A., Prodor na Balkan. Srbija u planovima Austro-Ugarske i Nemačke 1908-1918, Beograd 1981; Митровић А., Cpбија у Првом светском рату, Београд 1984; Екмечић М., Ратни циљеви Србије 1914-1918. г., Београд 1992; Поповић Н. Б., Срби у Првом светском рату 19141918. г., Београд 1998; Đ. Stanković, Srbija i stvaranje Jugoslavije, Beograd 2009.

20 стереотипима и слици „Другог“: Ristović M., , 'Slika neprijatelja': Srpske teme u berlinskom satiričnom časopisu „Kladderadatsch“ 1914-1915. godine“, Godišnjak za društvenu istoriju 1-2/1996, 23-39; Митровић А., „Срби о Немцима. Једно „виђење
} 
начин на који је друштво перцепирало Русију и Русе, ${ }^{3}$ као и русофилска расположења припадника српског народа. ${ }^{4}$

Николај Хенрикович Хартвиг је на положај у Краљевини Србији дошао 1909. године по окончању службовања у Персији. Био је начелник азијског департмана Министарства иностраних дела Русије, али и кандидат за министра те установе. ${ }^{5}$

Већ у првим српским реакцијама на његов долазак, приметна су била знатна очекивања и позитиван однос према придошлом. Извештаји са посланиковог путовања по „Новој Србији“, како је писано годину дана по ослобођењу Македоније, били су препуни израза одушевљења руским представником, који је био „тријумфално“ дочекан у Тетову пред 3.000 грађана. Оваква реакција „српског живља“, које је „тако дуго било потиштено“, у новинским чланцима описивана је као „сасвим разумљива“. ${ }^{6}$ Одушевљење, пак, поводом пада Скадра неколико месеци касније, подељено је и са Николајем Хенриковичем. Наиме, пред здањем руског посланства у центру престонице, одржане су манифестације, током којих је клицано императору Николају II, руском народу и „великом пријатељу Српства и Словенства“, представнику империје у Београду - Хартвигу. ${ }^{7}$ Почетком јулске кризе 1914. године међутим, његово име је постало предмет различитих критика у аустро-угарским круговима. Опту-

другог" створено историјом“, Срби о Немцима, ур. М. Софронијевић, М. Максимовић, Београд 1996, 11-16; Milosavljević O., U tradiciji nacionalizma ili stereotipi srpskih intelektualaca XX veka o,nama“ $i$ „drugima“, Beograd 2002; Ристовић М., Црни Петар и балкански разбојници. Балкан и Србија у немачким сатиричним часописима (1903-1918), Београд 2003; Makuljević N., „Slika drugog u srpskoj vizuelnoj kulturi XIX veka", Istorija i sećanje, Studije istorijske svesti, ur. O. Manojlović Pintar, Beograd 2006, 141-157; Јовановић М., „О „две Русије“ у српском друштву или Русија за „унутрашњу употребу“: слика Другог као идентитетско самодефинисање“, Срби о Русији и Русима. Од Елизавете Петровне до Владимира Путина (1750-2010): Антологија, при. М. Јовановић, Београд 2011, 11-40.

3 Антиаустријска расположења у Србији су била изражавана у више наврата, попут реакције јавности, коју је изазвао посланик Двојне монархије Угрон, који није присуствовао помену преминулим члановима династије Романов у Саборној цркви (одржаном поводом 300-годишњице њихове владавине) фебруара 1913. г. Наиме, штампа се изразито критички понела према одсутном представнику Аустро-Угарске, али и млађем аташеу и лакеју, који су уместо њега били на опелу. Политика, 21. 2. 1913, 3.

4 Јовановић М., Срби и Руси 12-21. век- историја односа, Београд 2012.

5 Штрандман В. Н., Балканске успомене, Београд 2009.

6 Правда, 13. 1.1913, 2.

7 Политика, 11. 4. 1913, 3. 
жен је био да поводом убиства Франца Фердинанда на згради своје резиденције није спустио заставу на поља копља. ${ }^{8}$ Овакви гласови су представљали разлог због којег је посетио аустријско посланство и њеног представника у Краљевини Србији - барона Гизла од Гислингена 27. јуна/10. јула (по новом календару). У тој згради у Београду, у току разговора са послаником Двојне монархије, доживео је срчани удар и упокојио се. ${ }^{9}$

Његова смрт је у периоду јулске кризе и предвечерја Првог светског рата имала карактер танатополитичке - политичке употребе смрти и сећања на мртве. Радило се о вештини коришћења смрти зарад политичке добити, умећу које је било практиковано вековима. Са политичког становишта, насилна смрт је била кориснија од природне, с тим да је успех у танатополитичким ритуалима био условљен начином умирања, али и степеном потребе, коју је преминули могао да задовољи. Стога је разумљиво што је погибија у рату била политички најупотребљивија. ${ }^{10}$ Истовремено, ништа мање важно није било и објашњење саме смрти. Она је, наиме, углавном представљана као последица деловања „оних”, „других” - односно, непријатеља јавно прокламованих у званичном дискурсу.

Хероизација жртава и демонизација непријатеља су, заправо, представљали уобичајене методе танатополитичке праксе. У том смислу су биле значајне сахране оних личности које су политички и идеолошки биле компатибилне властодршцима. Ти погреби, углавном у организацији представника власти, имали су функцију афирмације и ширења нових идеја, симбола, промене или очувања политичког курса, конституисања идентитета заједнице, али и одржавања јединства у важним, преломним друштвеним или политичким околностима. Пропратни ритуали је требало да осигурају подршку политичкој групи на власти или оној, која је претендовала ка институционалној моћи. ${ }^{11}$ Они су били праћени специфичном реториком која је, упркос извесним разликама у пракси, имала универзални мото и циљ - давања смисла смрти. Најилустративнији и најучесталији пример је свакако била изјава: „Умро је да бисмо ми живели”. ${ }^{12}$

8 Штрандман В. Н., Балканске успомене, Београд 2009.

9 Политика, 28. 6. 1914, 3.

10 Kuljić T., Tanatopolitika. Sociološkoistorijska analiza političke upotrebe smrti, Beograd 2014, 40, 47.

11 Isto, 44-45, 59-60, 63.

12 Isto, 32, 36. 
У погребним церемонијама важно је приметити неколико њених важних сегмената - идентификовати преовлађујућу форму ритуала (војничка, клерикална, цивилна); говорнике и оне којима се упућују поруке изречене у оквиру опроштајних говора; преовлађујуће елементе у реторици (верски, световни, партијски, државни, национални); карактер те реторике (ослободилачки, помиритељски, реваншистички); њено средиште (правда, отаџбина, нација); особине покојника које се евоцирају (регионални, државни, наддржавни ауторитет); учеснике церемонијала. ${ }^{13}$

Вест о смрти руског посланика при српском двору је заузела централно место у београдској штампи. „Правда“ је о Хартвиговој смрти обавестила своје читаоце натписом о „страшној ноћи“ коју је Београд имао између 27. и 28. јуна (по старом календару). „Наш највећи пријатељ, престао је да од синоћ живи за своју велику царевину, за Словенство, за српски народ, који је тако жарко волео.“14 Ова вест је, међутим, већ тада у јавности била пропраћена гласинама о „правом узроку“ смрти - наводном тровању покојника. Аутор новинског чланка, који је пренео ову вест, дао је слику атмосфере која је владала у престоници. Наиме, према његовим наводима, само су појединци поверовали у тврдњу о природној смрти (од срчаног удара), за разлику од већине, која је била упорна у свом уверењу да је био отрован, тврдећи притом да је велики пријатељ био жртва „аустријске помаме“. 15 „Многи који су то синоћ тврдили, говорили су о томе са таквим уверењем, као да већ и доказе имају у рукама." 16 Таква уверења су правдана гласинама да су аустријске власти именовале Хартвига за правог творца атентата у Сарајеву.

Околности под којима је представник Русије преминуо, према наводима Василија Николајевича Штрандмана, тадашњег првог секретара руске мисије у Београду, у српском друштву су изазвале појаве екстремних осећања, као и напетост у престоници. ${ }^{17}$ По улицама и на разним местима свет се нервозно скупљао, јурио у правцу руског посланства и тражио обавештења о узроку смрти. ${ }^{18}$ За овакво понашање београдска штампа је налазила оправдање да је станов-

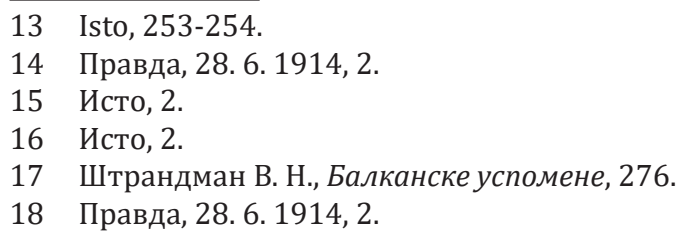


нике обузела жалост и „сваки је тражио начина, како ће ту трагедију објаснити и кога ће као проузроковача обележити. "19 Управо услед ширења наведених гласина, Штрандман је упутио молбу председнику министарског савета Николи Пашићу да предузме мере како би се истина што шире разгласила. Такође, с циљем утврђивања узрока смрти, односно оповргавања гласина о тровању, по секретаревој жељи, тело посланика је балсамовано. Установљено је да је посланик преминуо природном смрћу ${ }^{20}$

Слику свеопште жалости за покојником, могуће је илустровати и реаговањем читавих група. Наиме, у такозваном Бранином позоришту (сатиричном театру Бранислава Цветковића), на половини представе, објављена је вест о смрти посланика, и она је прекинута. И у биоскопима „Касина“, „Коларац“ и „Колосеум“ испуњеним многобројним гледаоцима, на вест о Хартвиговој смрти, „све је на мах стало“. ${ }^{21}$ Општедруштвена жалост за покојником, резултирала је и отказивањем биоскопских представа и обуставом свирања музике у престоничким кафанама, ${ }^{22}$ истицањем црних застава на свим кућама главних београдских улица, ${ }^{23}$ али и служењем религијских обреда.

У црквама у Краљевини су већ 28. јуна држани помени преминулом. Илустрацију карактера који је задобио овај религијски обред, дат је следећим описом: „српски сељак, остављајући свој пољски посао, журио је црквама да тихом молитвом Богу ода последњу пошту сени човека, који у истини има врло велики део заслуга за данашњу величину наше отаџбине. “24 Истог дана, према извештајима београдских листова, житељи главног града су се опраштали са покојником, чије је тело било изложено у згради посланства. „Политика“ је забележила и један разговор између двојице мушкараца: „Навалио свет, хоће да уђе, да види екселенцију”, жали се младић, гурајући врата.

- Пусти нека уђе ко год хоће, јер то је био њихов Никола Хартвиг - озбиљно је одговорио стари портир, који је имао пуне очи суза." 25

Описивана је маса света која је стајала испред тог здања, утученост и плач. „И мало и велико и просто и интелигентно, покушавало је да уђе у посланство, да види последњи пут великог пријатеља

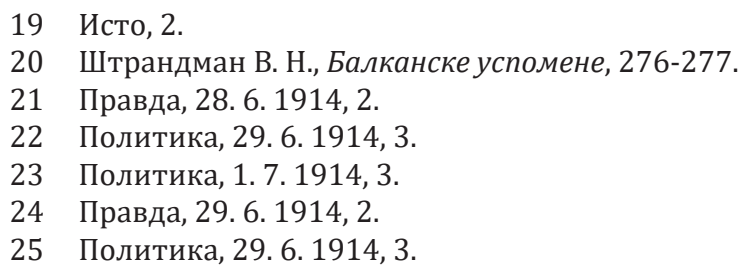


српског народа. Улазак се није бранио, али су га маса кола и аутомобили спречавали, тако да су многи са пуним срцем морали одустати од жеље“, ${ }^{26}$ извештавали су дописници. На опроштај са покојником су позивали и новинари престоничких гласила, истичући да је дужност сваког Београђанина да се опрости са послаником који је „био наш брат, највећи Србин. ${ }^{27}$ Услед великог броја придошлих, полицијски чиновници су били приморани да регулишу проток људи. Штампа је писала да је поред Хартвиговог тела „продефиловала цела српска престоница. “28

Истовремено, у српском јавном дискурсу, смрт је описивана као тежак удар, који је нанет српском народу након Сарајевског атентата. Истицано је да је смрт дипломате представљала „ненадокнадиви губитак Словенства, а особито Српства, које је он волео, као што мајка своје мезимче ${ }^{29}$ воли“. ${ }^{30}$ Овакве наводе је потврдио и Штрандман, који се критички изражавао о Хартвигу: „иако је грешио у односу на Русију, искрено је волео и поштовао српски народ и понекад му је на жртву приносио чак и интересе своје отаџбине ${ }^{31 “ .32}$

Убрзо по упокојењу, штампа је преносила различите вести о сахрани посланика. Првобитне информације, којима су новинари београдских редакција располагали, указивале су на то да ће у року од два дана његово тело бити пренето у Петроград и тамо бити

26 Политика, 29. 6. 1914, 2.

27 Правда, 28. 6. 1914, 2.

28 Политика, 1. 7. 1914, 3.

29 О перцепцији односа Русије према Србији сведоче речи кнеза Григорија Николајевича Трубецког, руског посланика на српском двору 1914-1915. г.: „Бугарска је била вољено чедо, а Србија наше занемарено пасторче“. Трубецки Г. Н., Рат на Балкану 1914 - 1917. и руска дипломатија, Београд 1994.

30 Правда, 29. 6. 1914, 2.

31 Према наводима члана организације „Уједињење или смрт“ Божина Симића, којем је током путовања по Русији омогућен приступ важним документима о спољној политици Русије, потом објављеним у часопису „Нова Европа“, руски посланик је из Београда заправо водио самосталну спољну политику: „Хартвиг је тврдоглаво саботирао сва наређења из Петрограда када нису била у складу са његовим планом.“ Он је, заправо, како је Симић забележио, тежио „оружаној борби, и то у првом реду са Аустро-немцима, а тек узгред са Турцима“. Чак је тврдио да је Николај Хенрикович „енергично заузео фотељу Пашића“, односно да је водио спољну политику Краљевине Србије. Мarco, „Никола Хартвиг и Србија“, Nova Evropa, br. 6, 26. 6. 1933, 243-244. Чланак је објавио под псеудонимом Маrсо. Я. В. Вишняков, Военный фактор и государственное развитие Сербии начала ХХ века, Москва 2012, 30.

32 Штрандман В. Н., Балканске успомене, 281. 
сахрањено. Према тим изворима, планирано је било служење опела у Вазнесењској цркви и потом пренос преко Пеште у руску престоницу. ${ }^{33}$ Друге, пак, информације су гласиле да ће његово тело бити пренето у Саборну цркву, у којој ће остати до момента слања у Русију (писано је да ће бити сахрањен у лаври Александра Невског у Петрограду). ${ }^{34}$ Извештачи су, међутим, пренели и верзију према којој ће његово тело бити привремено сахрањено на Новом гробљу, а затим пренето у Русију. ${ }^{35}$ Али, истовремено са овим нагађањима и разним информацијама, објављена је и жеља Београђана да се покојник сахрани у српској престоници. Тада је као последња вест стигао и телеграм удовице да „ће се по нарочитој жељи“ њеног супруга ова замисао и остварити. ${ }^{36}$

Идеја о погребу посланика у Београду појавила се већ исте ноћи када је Хартвиг преминуо и њу су исказале многе личности Штрандману. ${ }^{37}$ „Политика“ је већ дан по објави посланикове смрти пренела вест да је ћерка преминулог изразила „на меродавном месту“ жељу да се њен отац сахрани у Београду. Иста замисао је постојала и међу представницима градске општине, која ју је изложила у облику молбе; али и према извештају „Политике“, београдским грађанима. ${ }^{38}$ Наиме, замисао једне групе виђенијих београдских политичара, чиновника и грађана, описана као спонтана, била је да упуте молбу српској влади да посредује код породице покојника и царске владе да одобри да се посланик сахрани у престоници Краљевине Србије. ${ }^{39}$

Позитивни одговор руске владе, односно министра иностраних дела Сергеја Дмитријевича Сазонова, објавила је „Политика“: „Царска-руска влада веома дирнута жељом краљевске српске владе и града Београда, гледа у томе знак пажње, коју Србија указује посмртним остацима руског представника и сматра то као високу почаст за Русију. Дубоко благодарим на толикој пажњи и почасти, изјављујем да од стране царске владе нема никаквих сметњи за остварење ове српске жеље“. ${ }^{40}$ На питање, пак, упућено удовици да ли је дала пристанак да буде сахрањен у Београду, она је одговорила: „Како не бих

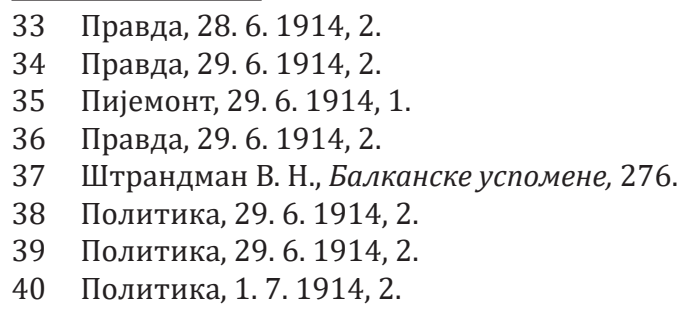


пристала? Па то је његова жеља и била! Толико ми је пута причао: „Баш је диван овај српски народ. Ништа не бих толико волео, колико да међу Србима и умрем“. ${ }^{41}$ Закључила је: „Нека гроб међу Србима настави посао, на коме је он за живота с толико љубави радио“. ${ }^{2}$

Према пројекту о уређењу Новог гробља, део у којем је био сахрањен Велимир Теодоровић, задужбинар и ванбрачни син кнеза Михаила Обреновића, и Милован Миловановић, био је предвиђен за гробове великих добротвора, пријатеља и великана, а план градских власти је био да се тај део касније украси колонадом и аркадама. По добијању сагласности од руске владе, Београдска општина је донела одлуку да се управо на том месту сахрани Хартвиг. ${ }^{43}$

Церемонијал самог погреба заказаног за 1. јул (по старом календару) разрадила је српска влада у складу са високим покојниковим звањем и према наводима Штрандмана, осећањима која је према његовој успомени гајио српски народ. Такође, она је на молбу првог секретара руске мисије предузела и мере како би се унапред спречиле евентуалне антиаустријске манифестације, имајући у виду гласине о тровању. Пашић је пристао да ограничи број говорника на три - то су били митрополит, он сам и градоначелник. Истовремено, преко Пресбироа су поново објављене стварне околности Хартвигове смрти, уз истицање неистинитости гласина непријатељских према Аустрији. Упркос бојазни, иступа против аустро-угарске мисије није било - Гирс је изашао из групе дипломата чим је погребна поворка која је кренула из Саборне цркве стигла до хотела „Гранд“ у улици краља Милана. Ипак и сама аустро-угарска мисија је предузела превентивне мере, упутивши на дан сахране чланове својих породица у Земун. ${ }^{44}$

У броју, објављеном на сам датум погреба, новинар „Политике“ је изразио своје становиште да ће сахрана посланика „остати у успомени као нешто, чега никада пре тога није било. Никада још, ни у једној земљи, није један стран посланик сахрањиван и оплакиван тако искрено и тако дубоко, као што Николу Хартвига жали и оплакује српска престоница и цела земља“. ${ }^{45}$

\footnotetext{
41 Исто, 2.

42 Исто, 2.

43 Пијемонт, 1. 7. 1914, 2.

44 Штрандман В. Н., Балканске успомене, 278.

45 Политика, 1. 7. 1914, 3.
} 
О детаљима погреба београдска штампа је известила своје читаоце, посветивши овом догађају знатан простор. Покушавајући да публици пренесе атмосферу и илуструје масовни карактер сахране, новине су објавиле запажања угледног гостионичара Косте Гинића, која је изговорио сузних очију једној групи новинара: „Још нико код нас није био овако сахрањен, нико сем можда блаженопочившег кнеза Михаила... али оваквог погреба у Београду још није било“. ${ }^{46}$ И сам аутор чланка „Политике“, о својим утисцима је записао да се не могу „ни речима ни сликом представити“. ${ }^{47}$ По процени овог листа, на главним градским улицама се окупило око 100.000 људи, ${ }^{48}$ што би одговарало укупном броју тадашњих становника Београда. ${ }^{49}$

Дописници са овог догађаја су извештавали да су још од раног јутра становници почели да се скупљају у околини руског посланства, трговци да затварају радње. ${ }^{50}$ Трупе београдског гарнизона су с обе стране улица којим је поворка требало да крене образовале шпалир - од посланства у Улици краља Милана, Кнез Михаиловој и краља Петра до Саборне цркве и од Теразија Александровом улицом до тада нове зграде Народне скупштине. Новинар београдског листа је приметио ред који је владао пре и током кретања поворке одајући поштовање и полицијским органима и грађанима који су се с пијететом односили према покојнику. На челу колоне се кретао одред коњичке жандармерије, иза којег су ношени крст и кољиво. За венцима су се кретале пешадијске трупе са музиком и командантима, затим десеторица официра који су носили покојникова одличја и ленте, као и певачка друштва. Ковчег, на којем су били украшени мач и Хартвигова парадна капа, из посланства су изнели официри и чиновници министарства иностраних послова. У Саборној цркви су спровод дочекали престолонаследник Александар, краљевић Ђорђе и принц Павле Карађорђевић. Опело у цркви је служио митрополит Димитрије са владикама и целокупним свештенством.

После службе, говор је одржао најпре митрополит, потом и Пашић. Његово обраћање је било значајно имајући у виду да је он био једини државник, који је задобио могућност да изрази своје

46 Политика, 2. 7. 1914, 2.

47 Исто, 2.

48 Исто, 2.

49 Београд је 1910. г. имао око 90.000 становника. Историја Београда 3, Двадесети век, Београд 1974, 157.

50 Политика, 1. 7. 1914, 3. 
мишљење о покојнику, мишљење које је истовремено имало снагу излагања званичне политике и званичног односа према руском дипломати (уосталом, и његов говор је био у целости објављен у „Политици“ за разлику од митрополитовог обраћања које уопште није било одштампано). У свом говору председник министарског савета се осврнуо на посланикове особине и делатност, поменувши, не без разлога, да се током службовања у Београду упознао и „спојио још јаче“ са тежњама „српског племена“, које су „увек биле и остале у сагласности с тежњама великог руског народа“. ${ }^{51}$ Продужавајући ту мисао наводима да се српски народ од Русије „није одвајао ни у најтежим моментима“, односно да је Хартвиг помагао српском народу „у најтежим тренуцима“, 52 дао је основу за уобличавање једне идеје. Са танатополитичког аспекта она је била још директније изражена у обећању да ће предати потомству да чува и поштује Хартвигов гроб, који ће „остати вечита веза између два народа, која ће пружити и поуку потомству да је велики преображај Србије остварен уз помоћ Русије“. ${ }^{33}$ Цитирана изјава је, чини се, сумирала важност која је дата преминулом руском посланику. Његова смрт, не занемарујући реакцију становништва престонице (уз сву њену ирационалност), притом потврђену мемоарима човека који није гајио позитиван став према Хартвиговој политици, у политичком смислу је била искоришћена за још јаче везивање за Русију и тражење њене помоћи и подршке у условима јулске кризе $1914,{ }^{54}$ али и остварења

\section{1 Политика, 2. 7. 1914, 3.}

52 Политика, 2. 7.1914,3.

53 Политика, 2. 7. 1914, 3.

54 Након што је Србија добила ултиматум од Аустро-Угарске, император Николај II је упутио телеграм регенту Александру, у којем је руски самодржац обећао да „ни у ком случају Русија неће бити равнодушна према Србији“. Поповић $\mathrm{H}$. Б., Односи Србије и Русије у Првом светском рату, Београд 1977; Поповић Н. Б., Србија и царска Русија, Београд 1994. Руска помоћ Краљевини Србији током Првог светског рата била је свесрдна. Поповић Н. Б., Односи Србије и Русије у Првом светском рату (1914-1918), Београд 1977; Поповић Н. Б., Србија и царска Русија, Београд 1994; Йованович М., „Ленинским курсом: как русские защищали Белград от австрийских мониторов на Дунае (1914-1915)“, Родина 11/2010, 130 132; Каширин В., „Дунайская Одиссея лейтенанта Григоренко“, Родина 11/2010, 132-133; Шевцова Г. И., Руска добротворна помоћ Србији у ратовима 1912-1917, Београд 2010; Тимофејев А., Кремић Д., Руска војна помоћ Србији за време Првог светског рата, Зборник грађе, Београд 2014; Тимофејев А., „Руско-српска војна сарадња почетком Првог светског рата“, Први светски рат, Србија, Балкан и велике силе, зборник радова, ур. С. Рудић, М. Милкић, Београд 2015, 167-180; Вишняков Я. В., Тимофеев А. Ю., Милорадович Г., Битва двуглавых орлов. Очер- 
других циљева. ${ }^{55}$ Идеја тада зачета наставиће да се развија и у међуратном периоду, у којем ће ослобођење и уједињење бити приписивано и помоћи Русије.

По завршетку опроштајних говора, ковчег су из цркве изнели представници дипломатског кора, заједно са Пашићем. „Политика“ је забележила да се по изласку из цркве поворка увећавала, а да је сам спровод трајао читава четири сата. ${ }^{56}$ Заправо величину ове манифестације најилустративније представљају кадрови филма „Погреб Николаја Хартвига“ који је снимио престонички филмски продуцент Ђорђе Богдановић, власник биоскопа „Касина“. ${ }^{57}$ Непрегледни редови учесника у погребу и шпалири грађана одлично одсликавају атмосферу која је тада владала у Београду.

Пред гробницом, ковчег са кола су скинули председник општине и већници. По читању молитве за покој душе, председник општине је одржао говор, у којем је исказао захвалност Срба што им је кад је смрт рано отргла великог пријатеља, била бар додељена утеха, да гроб Хартвигов буде у српској земљи. Ни његово обраћање, међутим, није било лишено танатополитичког садржаја. Дајући на известан начин потпору Пашићевим речима, указао је на значај и улогу гроба покојника у продужавању везе између Србије и „велике Русије“. 58

Сам погреб је био завршен испаљивањем топовских и пушчаних плотуна. ${ }^{59}$ Већ неколико дана након сахране, у београдском биоскопу „Касина“, приказан је филм „Погреб Николаја Хартвига“.

Са меморијализацијом посланиковог имена, започето је већ истог месеца. Наиме, Одбор Београдске општине је дан пре саме сахране, на својој свечаној седници донео једногласну одлуку да се дотадашња Београдска улица именује по преминулом (мада се на реализацију ове одлуке чекало више година). ${ }^{60}$ Почетком јула месеца, у селу Варварину, у црквеној порти недалеко од споменика руским добро-

ки по истории русско-сербских отношений в годы Первой мировой войны, Москва 2016.

55 Stanković Đ. Đ., Nikola Pašić, saveznici i stvaranje Jugoslavije, Beograd 1984; Екмечић М., Стварање Југославије: 1790-1918, Београд 1989.

56 Политика, 2. 7. 1914, 3.

57 Косановић Д., Почеци кинематографије на тлу Југославије 1896-1918, Београд 1985.

58 Политика, 2. 7. 1914, 3.

59 Исто, 3.

60 Пијемонт, 1. 7. 1914, 2. 
вољцима (чиме је на неки начин прављена аналогија и веза између погибије руских војника током српско-турских ратова и Хартвигове смрти), ${ }^{61}$ одржан је помен преминулом, који су служили сви тамошњи свештеници, а по завршетку опела, општински одбор је донео одлуку да се једна улица у варошици назове именом преминулог. ${ }^{62}$

Развој култа преминулог посланика, чије су назнаке биле уочљиве још од тренутка његовог доласка на службовање у Србију, уследио је одмах по објави вести о упокојењу. Русофилска осећања већине поданика Краљевине резултирала су панегиричним натписима у штампи, која је и сама давала различите интерпретације његове смрти. Њен опис у јавном дискурсу, ишао је чак дотле да је представљана као ратничка: „На том послу је и умро, као војник који умире на бојном пољу. Слава му је и вечан помен међу Србима, где год да их има и колико год да их има“. 63 Овакви наводи су и касније понављани, с тим да је ова „погибија на бојном пољу“ била повезивана и са акцијама аустријских власти - „његова смрт, свом трагичношћу својом, открила је на један јасан и потпун начин читав систем аустријских махинација и интрига“. 64 Пишући о „простој, обичној аустријској лажи“ да руско посланство поводом смрти Франца Фердинанда није спустило заставу на пола копља и да је организовало поједина весеља, аутор једног новинског чланка је реконструисао Хартвигову посету аустријском посланику: „Болестан, узнемирен, већ срчаним нападима и онда није никакво чудо - напротив лекарски је то сасвим разумљиво - што га је у експликацији коју је имао са г. Гизлом ударила капља. Војник је пао, вршећи своју дужност“ . 65

Завршетком рата и стварањем Краљевине Срба, Хрвата и Словенаца, његов лик није нестао из јавног дискурса. Напротив, био је присутан (у том периоду је и Београдска улица преименована у Хартвигову, иако је ово решење било донето још 1914. г.). ${ }^{66}$ На његову делатност, београдска гласила су подсећала своје читаоце, одржавајући на тај начин успомену на почившег, док су сами натписи у штампи следили традиције оних извештаја из јула 1914. године. Реактуелизовано је питање узрока његове смрти, праћено понављањем раз-

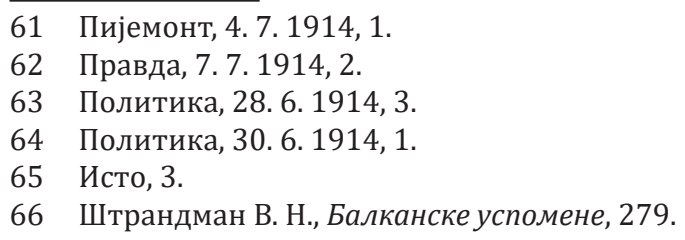


личитих верзија догађаја и интерпретација. У том смислу је био интересантан чланак објављен у београдској „Правди“ фебруара 1927. започевши извештај понављањем приче о „тајанственој, нерасветљеној и изненадној“ смрти посланика, аутор је поставио питање шта је дипломату толико узбудило да је имао срчани удар? Самог покојника је описао као „знаменитог представника доброг словенског цара“,67 док је природним сматрао постојање различитих гласина које су тих јулских дана у Београду препричаване. И 1931. године настављено је са сличним причама о наводном убиству Хартвига: „Препирало се око тога, да ли је кафа била отрована или је столица била електризована“. 68

Посебан повод за поновно отварање тог питања, представљала је двадесетпетогодишњица од његове смрти. Тада су у листу „Време“ објављене успомене публицисте Душана Лончаревића. Он је 1914. године као новинар, дописник Корбироа, пратио догађаје који су претходили аустро-угарском ултиматуму Србији. Писао је о „фантастичним околностима под којима се изненада угасио живот великог и незаборавног пријатеља српског народа и свих Јужних Словена“, што је изазвало у Београду „запрепашћење и неизмеран бол“.69 С обзиром да је по приспећу вести о смрти посланика као дописник стране новинске агенције кренуо у аустријско посланство, пролазећи поред кафане „Руски цар“, његов неименовани пријатељ му је довикнуо: „Пожури, Гизл нам је отровао Хартвига“. ${ }^{70}$ Сам аустро-угарски посланик је Лончаревићу испричао да је разлог доласка руског дипломате било демантовање оптужби о његовом наводном некоректном понашању у вези са парастосом Францу Фердинанду (да је закаснио на помен у католичкој цркви и да није носио униформу), као и са стављањем заставе на пола копља. ${ }^{71}$

Исти јубилеј је представљао повод за дописника тог листа да обави и разговор са удовицом дипломате. Тај дијалог је додатно учврстио начин на који је српска јавност перцепирала Хартвига и поновно актуелизовао идеју о свесном жртвовању за српство, али и верзије о узроку смрти. У разговору, удовица се присетила речи своје пасторке Људмиле, која је на њену констатацију да је посланик био

67 Правда, 3. 2. 1927, 3.

68 Време, 7. 3.1931, 1.

69 Време, 10. 7. 1939, 5.

70 Исто, 5.

71 Исто, 5. 
здрав, одговорила да је „увек био нервозан кад год је видео барона Гизла“. ${ }^{72}$ Испричала је да се не сећа да ли јој је аустро-угарски посланик изјавио саучешће, као и да њен муж није био болестан. ${ }^{73}$ Покушала је чак и да реконструише ту ситуацију: „Сам догађај у соби аустро-угарског посланика није довољно објашњен... Ја сам знала како се Николај осећао чим би видео барона Гизла. Врло је вероватно да се мој муж раздражио или да је био увређен. Кад је била у питању Србија, ту Николај није могао бити равнодушан. Ако је Гизл нешто рекао што није било пријатно Николају, као човеку коме је дубоко лежала на срцу слобода Србије, морало је доћи до реакције. Николај је свакако почео да виче, и то га је убило. Може се претпоставити чак да је Гизл рекао Николају да Аустрија не жели да види Србију као огњиште слободе Јужних Словена. Николај је сматрао да је то противно не само конвенционалним прописима међународног морала, него и чисто људским обзирима. То га је убило, јер је Николај био човек који је, пре свега, на свету ценио слободу и поштовање туђег права. А осим тога, више но свој живот, волео је Србију“. ${ }^{74}$ На крају разговора, према наводима новинара „Времена“, рекла је: „Био је велики Србин“! 75

За разлику од цитираних навода, исте те године, поводом свечаног откривања споменика руском посланику новембра 1939, (двадесет и пет година након његове смрти), дата је реалистичнија оцена самих околности и узрока смрти дипломате. Божин Симић је анализирао ту ситуацију речима: „Вест о његовој смрти у аустријском посланству врло је подозриво примљена у Београду. Разуме се, о његовом тровању од стране Аустријанаца, не може бити говора“. ${ }^{76}$ Ипак, ни његово расуђивање није било лишено емоција: „његова судбина као да је хтела да му учини бар ту милост, да својом смрћу зада последњи ударац и последњу непријатност своме крвном непријатељу (Аустрији - М.Ж.)“. ${ }^{77}$

Дискусије око узрока смрти руског посланика у Београду Николаја Хенриковича Хартвига у српском јавном дискурсу започете су

72 Време, 16. 7. 1939, 12.

73 Овим речима се супротставља забелешка Штрандмана о томе да је доктор који је прегледао тело преминулог нагласио да би руски посланик због лоших крвних судова вероватно умро веома брзо. Штрандман В. Н., Балканске успомене, 277.

74 Време, 16. 7. 1939, 12.

75 Исто, 12.

76 Политика, 12.11.1939, 6.

77 Исто, 6. 
објавом ове вести и трајале су више од две и по деценије. По завршетку Првог светског рата је настављено са препричавањем и преношењем пређашњих гласина о томе да његова смрт није била природна. Овакве реакције могу се објаснити развојем култа Хартвиговог имена, који је почео да се гради скоро од самог момента његовог доласка на службовање у Београд. То је, међутим, био један од фактора. Наиме, перцепција смрти руског дипломате, као и сам погреб организован у Београду, уз учешће великог броја житеља престонице, представљали су последицу више чинилаца, у које су спадала и русофилска расположења становништва, али и друштвене и политичке околности настале Сарајевским атентатом. Његова смрт је, пак, у политичком смислу, у условима Јулске кризе, чини се, била искоришћена за још јаче везивање за Русију. 